\title{
KNOWLEDGE SPREAD IN LITHUANIA IN TERMS OF PUBLISHED PATENT APPLICATIONS
}

\author{
Arimantas BRonisLovas KNašAs ${ }^{1}$ \\ Klaipeda University (Lithuania)
}

\begin{abstract}
The main processes of knowledge management are analyzed in this publication. Spread of knowledge was evaluated by analyzing published patent applications. All published applications for inventions subdivided into the three groups. The number of applicants (inventors) in the separate application are ascertained. The number of published applications in the International Patent Classification sections for the 2005-2014 years are ascertained. Selecting published applications R\&D and high technology development directions are described.
\end{abstract}

KEY WORDS: knowledge creation, knowledge value, intellectual capital, patent application.

JEL CODES: D80, O31, O34.

DOI: http://dx.doi.org/10.15181/rfds.v14i3.869

\section{Introduction}

Actual or potential competition is generally considered a primary driver of innovation. Global competition as the foundation of industrialized economics has shifted from natural resources to intellectual assets in such a way that current era is titled knowledge era. It is now widely recognized that global competitiveness is dependent on the capacity of economies to acquire knowledge capital and to apply new knowledge through a highly trained and specialized workforce. Firms have always been oriented toward accumulating and applying knowledge to create economic value and competitive advantage and the need to do it has never been more. The term "knowledge-based" or "learning economy" has emerged to describe those economies in which the production, distribution and use of knowledge are the main drivers of growth, wealth creation and employment across all industrial sectors.

Problem: to determine the spread of knowledge in Lithuania is necessary to investigate submission of an applications to Patent Office.

Purpose: to produce the situation of published applications.

Object: invention applications published under 21 and 26 articles of Lithuania Republic Patent Law.

Tasks of the article:

- To review literature (scientific and official documents) of knowledge management.

- To investigate situation of published applications for 2015-2014 years.

Methods: analysis and summary of scientific literature and official documents, selection of published applications from The Official Bulletin of the State Patent Bureau of the Republic of Lithuania for 20052014 years.

1 Arimantas Bronislovas Knašas - associate professor, doctor of social science, Klaipèda University, Faculty of Social Sciences. Scientific interest: innovation management, patentology

E-mail: abknasas@gmail.com

Tel.: +370648 89213 


\section{Knowledge}

Knowledge can be considered in a variety of ways. Classifying knowledge helps organizations to identify the different types of knowledge. The organization that wishes to cope dynamically with the changing environment must be able to create knowledge better and faster than its competitors (Bratianu, Orzea, 2010). Knowledge creation is defined as a continuous process (Nejatian, et al, 2013). Creativity is associated with that part of the innovation process which is labeled as "idea generation" (Bratianu, Orzea, 2010). Within business and knowledge management (KM), two types of knowledge are usually defined, namely explicit and tacit knowledge. The former refers to codified knowledge, such as that found in documents, while the latter refers to non-codified and often personal/experience-based knowledge. Knowledge management and organizational learning theory almost always take root in the interaction and relationship between these two types of knowledge.

The first time term "knowledge worker" was mentioned by Peter Drucker in his work "Landmarks of To-morrow" (1959) (Daugelienė, 2007). The conception of knowledge workers presented in the latest works of Drucker (Drucker, 1986; Drucker, 1999; Drucker, 2002). According Drucker the most valuable assets of a $20^{\text {th }}$ century company was its production equipment. The most valuable asset of a $21^{\text {st }}$ century institution (whether business or non-business) will be its knowledge workers and their productivity. Six major factors determine knowledge-worker productivity (Drucker, 1999: 83-84).

- Knowledge-worker productivity demands that we ask the question: "What is the task?"

- It demands that we impose the responsibility for their productivity on the individual knowledge workers themselves. Knowledge Workers have to manage themselves. They have to have autonomy.

- Continuing innovation has to be part of the work, the task and the responsibility of knowledge workers.

- Knowledge work requires continuous learning on the part of the knowledge worker, but equally continuous teaching on the part of the knowledge worker.

- Productivity of the knowledge worker is not-at least not primarily-a matter of the quantity of output. Quality is at least as important.

- Finally, knowledge-worker productivity requires that the knowledge worker is both seen and treated as an "asset" rather than a "cost." It requires that knowledge workers want to work for the organization in preference to all other opportunities.

Peter Senge defines a learning organization as: "At the heart of a learning organization is a shift of mind - from seeing ourselves as separate from the world to connected to the world, from seeing problems as caused by someone or something "out there to seeing how our own actions create the problems we experience. A learning organization is a place where people are continually discovering how they create their reality. And how they can change it" (Senge, 2004: 13). Peter Senge (Senge, 2004) suggests that there are five "disciplines" associated with the learning organization: systems thinking, personal mastery, mental models, building shared vision, and team learning. Peter Senge's Fifth Discipline is a classic work in systems thinking (Pollock, 2002). Systems thinking expands individual thinking perspectives and improves individual and organizational decision-making. P. Senge (1990) emphasizes team learning and team skills rather than individual skills and individual learning as the key to competitiveness (OECD, 2000).

Karl-Erik Sveiby, author of the book The New Organizational Wealth (1997), has described "Ten Knowledge Strategy Issues" in a white paper entitled "A Knowledge-based Theory of the Firm to Guide Strategy Formulation" (Sveiby, 2001). This model is based on nine primary knowledge transfers, and seeks to maximize the enterprise-value as a whole. Sveiby presents this model as a way of understanding the enterprise from a "knowledge-based perspective".

Definition of knowledge in Oxford dictionary (Oxford dictionary, 2014): 1. Facts, information, and skills acquired through experience or education; the theoretical or practical understanding of a subject. 1.1. The sum of what is known: the transmission of knowledge. 1.2. Information held on a computer system. 1.3. Philosophy: True, justified belief; certain understanding, as opposed to opinion. 
Definition of knowledge in Meriam Webster's Collegiate Dictionary (Dictionary, 2014): information, understanding, or skill that you get from experience or education; awareness of something: the state of being aware of something; the fact or condition of knowing something with familiarity gained through experience or association: acquaintance with understanding of a science, art, or technique; the fact or condition of being aware of something: the range of one's information or understanding; the circumstance or condition of apprehending truth or fact through reasoning: cognition; the fact or condition of having information or of being learned; the sum of what is known: the body of truth, information, and principles acquired by humankind.

Nedella and Paun presented complex definition of knowledge: "Knowledge is a more operational and extensive concept than information from the content, meaning, value and size point of view, with a high level of context dependence and pattern understanding (considered as cumulated inventories of information describing reality at a profound level and allowing its transformation in order to reach certain objectives). Knowledge has the capacity to produce value and is the element on which individual and organizational competences are based on" (Nedella, Paun, 2009: 746).

The concept of tacit knowledge was originally developed by Polanyi (1958/1978 and 1966). Knowledge Management in the Learning Society patent (OECD, 2000). Polanyi in 1958 introduced the term into modern circulation by referring to a component of human knowledge distinct from but complementary to knowledge explicit in conscious cognitive processes. Much knowledge is transcribed into a language, onto a storable, transportable medium. It is thus codified-by the use of some code (a language) the knowledge is turned into messages. Tacit knowledge, by contrast, has not undergone this transformation. A standard example of tacit knowledge is the knowledge of how to ride a bicycle (Cowan, Gert van de Paal, 2000). Polanyi in 1966 argued that knowledge can be classified into two broad categories: explicit/codified knowledge and tacit knowledge. The first category is articulated and transmitted in formal language, including grammatical statements, mathematical expressions and models. It can be processed by computers, transmitted electronically or stored in databases. For example, patents, trademarks, business plans, marketing research and customer lists are all forms of explicit knowledge, which can be documented, archived and codified. Conversely, it is difficult (though not impossible) to articulate tacit knowledge in formal language as it comprises subjective insights, hunches and intuition. In a sense, it is context-specific and often lies within the individual. Tacit knowledge is obtained through experience and learning by doing. Very often, it is internalized to such an extent that it is taken for granted. In other words, it is know-how contained in people's heads (Sulaiman et al, 2009) Michael Polanyi in 1966 argues that human beings obtain new knowledge through their individual, active, and subjective shaping and integration of experience, which he calls "tacit knowing" (Soviar, Zavodska, 2011). As Michael Polanyi (1967: 4) wrote in The Tacit Dimension, we should start from the fact that "we can know more than we can tell". He termed this prelogical phase of knowing as "tacit knowledge" (Smith, 2003).

In 1985, product developers at the Osaka-based Matshusita Electric Company were hard at work on a new home-bread-making machine, but they were having trouble getting the machine to knead dough correctly. Software developer Ikuko Tonaka proposed a creative solution. Ikuko Tanaka's innovation illustrates a movement between two very different types of knowledge. The end point of that movement is "explicit" knowledge: the product specifications for bread-making machine. Explicit knowledge is formal and systematic. For this reason, it can be easily communicated and shared. But the starting point of Tanaka's innovation is another kind of knowledge that is not easy expressible-"tacit" knowledge". Tacit knowledge consists partly of technical skills the kind of informal skills captured in the term "know-how". At the same time, tacit knowledge has an important cognitive dimension. The distinction between tacit and explicit knowledge suggests four basic patterns for creating knowledge in any organization: 1. From Tacit to Tacit. 2. From Explicit to Explicit. 3. From Tacit to Explicit. 4. From Explicit to Tacit (Nonaka, 1991).

Bratianu and Orzea (Bratianu, Orzea, 2010: 42) emphasize "The study of literature revealed that there are three distinct phases of knowledge management: before the 90s, the early 90s and the late $90 \mathrm{~s}$ ". There are at least three accounts of generations of knowledge management: 1 . In the first phase of knowledge manage- 
ment mangers focused on data and information processing, and on information systems management. The goal was to observe, gather, store in data bases, and manage existing knowledge in information systems as any other assets. 2 . In the second phase, knowledge management focused on the organizational knowledge sharing process. 3. In the third phase the focus changed to the sources and stimulating factors of knowledge creation (Vorakulpipat, Rezgui, 2008; Bratianu, Orzea, 2010).

The theory of knowledge creation was first introduced by Nonaka (Nonaka, 1991). According Nonaka (Nonaka, 1991) in an economy where the only certainty is uncertainty the one sure source of lasting competitive advantage is knowledge. When markets shift, technologies proliferate, competitors multiply, and products become obsolete almost overnight, successful companies are those that consistently create new knowledge, disseminate it widely throughout the organization, and quickly embody it in new technologies and products. Nonaka formulated: "These activities define the "knowledge-creating" company, whose sole business is continuous innovation" (Nonaka, 1991: 162). As for the process function, knowledge managers can lead and facilitate knowledge creation, accumulation and sharing of tacit knowledge activities by socially nurturing a "good" Ba (physical and nonphysical environment) for converting individual knowledge into organizational knowledge (Nonaka and Konno, 1998), contrasting re-use and distribution of explicit knowledge in the Western tradition (Nonaka, Konno, 1998).

\section{Knowledge creation}

SECI model. The SECI model is the spiral, interaction process of knowledge conversion between tacit and explicit knowledge (Nonaka et al., 2000; Nejatian, et al., 2013). The theory of organizational knowledge creation defends that tacit and explicit knowledge are complementary and interact with each other in creative activities carried by individuals and groups. The knowledge conversion includes four modes: socialization, externalization, combination, and internalization. The socialization highlights the conversion of tacit to new tacit knowledge through shared experience (e.g. apprenticeship). The externalization mode focuses on the conversion of tacit knowledge to explicit knowledge by creating concepts articulating tacit knowledge (e.g. metaphor, analogy and model). The combination mode refers to the conversion of explicit knowledge to new explicit knowledge that is more systematic. The internalization mode refers to embodying explicit knowledge into tacit knowledge through learning by doing. It is required for organizations to establish place or space, "ba", to create knowledge. Four types of "ba" within the SECI process are identified: originating "ba", dialoguing "ba", systemizing "ba", and exercising "ba". Originating "ba" is a common place for sharing experience through face-to-face interactions. Dialoguing "ba" is a place where mental models and skills are articulated by common terms or concepts. Systemizing "ba" is a place of collective and virtual interaction, where people can have activities through on-line networks or any computer technologies. Exercising "ba" is the place for embodying explicit knowledge through virtual interaction (Nonaka, Konno, 1998). Knowledge assets are intangible resources that contribute to value creation. They can be inputs or outputs of the SECI process (Jafari, et a.1, 2009; Bratianu, Orzea, 2010).

Extended SECI model. Uotila et al. (2005) designed an extended version of the SECI model-two new knowledge conversion modes focusing on self-transcending knowledge (not yet embodied tacit knowledge) and two new "bas" are added to the extension model. Two additional modes are identified: visualization and potentialization. The visualization mode is the conversion from self-transcending to tacit knowledge through visions, feelings, mental model, etc. This mode takes place in "imagination ba". Forecasts, scenarios and expert-based statements can be made. A combination of scenarios and expert-based statements may be suitable. The potentialization mode is the conversion from tacit to self-transcending knowledge by sensing the future potentials and seeing what does not yet exist. The potentialization process takes place in "futurizing ba" (Nejatian, et al., 2013).

7C model. 1996 Prasad proposed seven elements (called 7Cs) to team cooperation philosophy (Prasad, 1998): 1. Collaboration: this describes a process of value creation that a traditional structure of communication and teamwork cannot achieve. 2. Commitment: empowered teams define the tasks and prioritize areas 
to make breakthrough opportunities. 3. Communications: effective communication is the precursor to meaningful collaboration. 4. Compromise: there is compromise and input from every discipline so that simultaneous development of the product, process, and associated tooling can be achieved. 5. Consensus: project team and management members may disagree on some issues, but teams' support on the requirements and a commitment to project objectives from the very outset is essential. 6. Continuous improvement: product or process design teams work toward the total elimination of waste. 7. Coordination: Coordination involves actors performing interdependent activities that achieve goals, and its analysis includes goal decomposition, resource allocation, synchronization, group decision making, communication and the preparation of common objectives. The "7C model" for understanding organizational knowledge creation is proposed by Oinas-Kukkonen (2004). The 7Cs (which consist of Connection, Concurrency, Comprehension, Communication, Conceptualization, Collaboration, and Collective intelligence) play a critical role in the knowledge creation process. The $7 \mathrm{C}$ model is described as the dimension of different contexts: technology, language, and organizational contexts. In the technology context, Internet "connection" can provide knowledge for several "concurrent" users. In the language context, "comprehending" and "communicating" are introduced as the important factors when information is provided to users. In the organizational context, knowledge "conceptualization" can articulate knowledge through interaction among people ("collaboration"). These six "C"s lead to a greater sense of togetherness and "collective intelligence". The 7C model is not linear, but a multiple-cycle spiral process. Four key phases or sub-processes driven within the knowledge creation exercise are proposed: comprehension, communication, conceptualization, and collaboration. Comprehension refers to a process of surveying and interacting with the external environment and embodying explicit knowledge into tacit knowledge by "learning by doing" (similar to internalization in the SECI model). Communication refers to a process of sharing experiences (similar to socialization in the SECI model). Conceptualization refers to a collective reflection process articulating tacit knowledge to form explicit concepts and systemizing the concepts into a knowledge system (similar to externalization and combination in the SECI model). Collaboration refers to a true team interaction process of using the produced conceptualizations within teamwork and other organizational processes (Oinas-Kukkonen, 2004; Oinas-Kukkonen, 2005; Raisanen, Oinas-Kukkonen, 2008).

Combined research model. To compete in a dynamic global market, the need for tools and decision-making technology increases. Heinrichs and Lim propose the "combined research model", combining organizational decision models and competitive intelligence tools. Four factors of knowledge creation and strategic use of information competence are identified (Heinrichs, Lim, 2005):

- Pattern discovery: pattern discovery drives organizations to create new knowledge from existing knowledge such as past decisions, past solutions, and diagnostic evaluation of past rules and models.

- Strategy appraisal: appraising the impact of a strategy is necessary before deciding to continue or develop new niches, and allows organizations to develop an historical knowledge base regarding the success and failure of past strategic decisions.

- Solution formulation: formulated solutions are key components affecting insight generation competence and can gain higher confidence of knowledge workers.

- Insight generation: Insight generation involves observing and interpreting charts, graphs, tables, and other information to derive meaningful ideas, directions, and solutions for the organization. Insights can provide guidance to innovative problem solving and strategic decision-making.

- Value creation: the third generation knowledge management.

\section{Knowledge value}

The relationship between value creation and knowledge management has been argued by several researchers.

One of the key authors in the area of intellectual capital is Sveiby (Sveiby, 2001), who has developed a knowledge-based theory of the firm to guide in strategy formulation. He distinguished between three fami- 
lies of intangible assets. The external structure family consists of relationships with customers and suppliers and the reputation (image) of the firm. Some of these relationships can be converted into legal property such as trademarks and brand names. The value of such assets is primarily influenced by how well the company solves its customers' problems, and there is always and element of uncertainty here. The internal structure family consists of patents, concepts, models, and computer and administrative systems. These are created by the employees and are thus generally owned by the organization. The structure is partly independent of individuals and some of it remains even if a large number of the employees leave. Competence can be defined as the sum of knowledge, skills and abilities at the individual level.

Bose (2004) presented some of the currently used measures for knowledge assets or intellectual capital. Bose affirm that presented metrics are very helpful and desirable for the purpose of identifying and development future measures. Currently used measures for knowledge (intellectual capital) (Bose, 2004):

- Based on the intellectual Capital Management (ICM) Group study in 1998: value extraction (including patents pending); customer capital; structural capital; value creation; human capital.

- Based on the Canadian Management Account's (CMA) 1999 report on measuring knowledge assets: including number of patent filed.

- Roos et al. (1998) developed the following indicators: human capital (competence, attitude, intellectual agility); structural capital (relationships, organization, renewal and development) - including revenues from patents.

- Based on the Universal Intellectual Capital Report: financial focus; customer focus; process focus; renewal and development focus-including average age of company patents and patents pending; human focus.

Qureshi and Briggs in 2006 suggest, that the key contribution is in making explicit the relationship between knowledge management and collaboration and in doing so explanatory power is provided to the Intellectual Bandwidth model. The Intellectual Bandwidth model posits a variation to the conventional hierarchy of understanding: data (understanding symbols in the context where they were collected), information (understanding relationship among data in the context in which they are presented), knowledge (understanding patterns in the context which they emerge) and wisdom (understanding principles-wisdom entails understanding the causes and consequences underlying patterns, and the context in which they manifest). The Intellectual Bandwidth model posits that an organization's potential to create value is determined by its intellectual assets and collaboration capabilities (Quereshi, Briggs, 2006).

Value creation is gradually being established as the third generation of knowledge management. Five major factors toward value creation emerge from the literature: 1. Human networks. 2. Social capital. 3. Intellectual capital. 4. Technology assets. 5. Change processes (Vorakulpipat, Rezgui, 2006; Vorakulpipat, Rezgui, 2007; Vorakulpipat, Rezgui, 2008).

In order to find out the prevailing methodological features among the intellectual capital measurement methods, the comparative analysis of different methods was performed by Vaškelienè (Vaškelienè, 2007). According to the results different intellectual capital measurement methods are based on different management paradigms, and differ in their theoretical background, methodological approach, number and type of indicators used, benchmarks applied, techniques implemented and other features. Brief results of the comparison of intellectual capital measurement methods included 30 titles of methods (including Citation-Weighted patents, Balanced Scorecard, Skandia Navigator) (Vaškelienė, 2007).

Mačerinskienè and Survilaite (Mačerinskienè, Survilaite, 2011) accentuates that intellectual capital is very important for company's value added and intellectual capital can increase it.

Todorova (Todorova et al., 2012) show that values generated by CreMS (Credit and relationship management system) fall into the following major categories: efficiencies; improved customer service and relationships; learning and collaboration; effectiveness; strategic response and compliance and risk reduction.

Skandia Navigator is a tool for evaluating financial and intellectual capitals. Skandia Navigator's intellectual capital index helps measure the changes (positive or negative) in a firms's overall market value based 
on both financial and intellectual capitals. A brief description of each intellectual capital element of the Skandia Navigator is: human capital; structural capital; customer capital; organizational capital; innovation capital expressed as intellectual property and other intangible assets and values; process capital; intellectual property-this is patents, trademarks, copyrights, designs and other specifications; other intangible assets-this is culture (Bose, 2004).

Several authors (Mouritsen et al., 2001; Gao et al., 2002; Bose, Thomas, 2007) saw the true value of knowledge in understanding the difference between visible and invisible intellectual capital and maximized the five success factors: (1) financial; (2) customer; (3) process; (4) renewal and development; and (5) human. Knowledge management became part of visualizing and cultivating knowledge (intellectual capital) and found ways to leverage an organization's intangible intellectual assets for more value. Along with knowledge management, organizations can create and utilize the best possible capital hidden in people's brain via tools for measuring and presenting intangible assets (Mouritsen et al., 2001; Gao et al., 2002; Bose, Thomas, 2007).

Ramanauskaite and Rudžionienè in 2013 described four groups of methods for intellectual capital valuation: 1. Classification according to general principles of valuation (Market Capitalization Methods-MCM; Return of Assets Methods-ROA; Direct Intellectual Capital Methods-DIC, including citation-weighted patents; Scorecard Methods-SC, including Skandia navigator, intellectual capital index. 2. Classification according to the valued objects (Holistic, Atomistic). 3. Classification according to the use of a monetary in the process of valuation (Monetary, Non-monetary). 4. Classification according to the expression of valuation result (Financial valuation, Value measurement, Value assessment, Measurement-including citation-weighted patents) (Ramanauskaitè, Rudžionienè, 2013).

The impact of knowledge management on an organization's performance is strongly tied to the ability of an organization to identify where knowledge management will be of most value that contributes to its market strength. In essence, intellectual capital is the knowledge capability of an organization to convert knowledge, skills and expertise into profitable intellectual assets, and include inventions, technical know-how, design approaches, computer software and programs. When these assets become protected by patents, copyrights, trademarks, and trade secrets, they assume the character of an intellectual property (Bose, Thomas, 2007). Intellectual property such as patents, technologies, ideas, and designs are what keep leading companies ahead of their competition.

Paris Convention for the protection on Industrial Property declare: "The protection of industrial property has as its object patents, utility models, industrial designs, trademarks, service marks, trade names, indications of source or appellations of origin, and the repression of unfair competition" (WIPO, 2014, article 1:2).

\section{Science and technology indicators}

The main challenges for science and technology indicators are manifold.

1. The Technology Balance of Payments (TBP) series are data extracted from national sources (balance of payments or survey results) with the aim of measuring the flow of technological know-how and services into and out of the country concerned. The OECD manual "Proposed Standard Method of Compiling and Interpreting Technology Balance of Payments Data", TBP Manual 1990, gives the methodology for the international standards for compiling such data. The TBP registers the commercial transactions related to international technology transfers. The series quoted comprise money paid or received for the acquisition or use of patents, licenses, trademarks, designs, inventions, know-how and closely related technical services and for industrial R\&D carried out abroad, etc (TBA manual, 1990).

2. It has been long understood that the generation, exploitation and diffusion of knowledge are fundamental to economic growth, development and the wellbeing of nations. Central to this is the need for better measures of innovation. Innovation is a continuous process. Over time the nature and landscape of innovation have changed, and so has the need for indicators to capture those 
changes and provide policy makers with appropriate tools of analysis. Globalization has led to dramatic increases in access to information and new markets for firms. Owing to advances in technologies and greater flows of information, knowledge is more and more viewed as a central driver of economic growth and innovation. The aim of the third edition of the Oslo Manual is to provide guidelines for the collection and interpretation of data on innovation. Firms constantly make changes to products and processes and collect new knowledge, and it is more difficult to measure a dynamic process than a static activity. With the objective of capturing this process, the Oslo Manual presents guidelines for collecting data on the general process of innovation (for example, innovation activities, expenditures and linkages), the implementation of significant changes in the firm (i.e. innovations), the factors that influence innovation activities, and the outcomes of innovation (Oslo manual, 2005).

3. The Patent Manual follows on from the TBP Manual (on international trade in technology) and the Oslo Manual (on innovation surveys), and is an essential item for fuller understanding of the process of technological innovation and dissemination. Alongside other science and technology indicators such as R\&D expenditure and personnel, data on the technology balance of payments, and so on, patents provide a uniquely detailed source of information on inventive activity. Patent data provide detailed information on countries' technological activities, covering long periods through the time series available. The main information that can be drawn from patent documents relates to the type of technology covered by the claim, the name and nationality of the inventor (individual, government agency, private corporation), links between a new patent and knowledge in earlier ones and scientific publications, the economic sector where the invention originated, and the fields and markets covered by the patents. The International Patent Classification (IPC) entered into force in 1975, under the Strasbourg Agreement of 1971 which determined its principles and form of operation. IPC is a retrieval system for inventions claimed in patent documents and for certain significant information only available in descriptions. IPC is designed so that each technical object to which a patent relates can be classified as a whole. A patent may contain several technical objects and therefore be allocated several classification symbols. An invention is normally classified according to its function or intrinsic nature, except when its application alone determines its technical characteristics. IPC is a tiered structure in which all techniques are classified in sections, classes, subclasses, groups and subgroups. Each subgroup may be further subdivided. Every patent document receives one or more classification symbols corresponding to the invention claimed in the application. So that the classification can be understood, the designations of the various IPC symbols are defined by IPC entry labels. Coding rules, applied generally or locally, have also been established. Examiners have precise instructions on how to classify a claim in accordance with the technical description. The International Patents Classification is revised and if necessary amended every five years, but not retroactively. The first edition of the Classification was in force from September 1, 1968 to June 30, 1974. From January 1, 2011, onwards, the division of the Classification into core and advanced levels was discontinued and each new version of the IPC is indicated by the year and the month of the entry into force of that version, for example, IPC-2011.01. Today IPC version-IPC-2014. It contains about 80000 entries, each represented by an alphanumeric symbol corresponding to one of the tiered divisions in the classification (WIPO, IPC full edition, 2014). Database Espacenet offers free access to more than 80 million patent documents worldwide, containing information about inventions and technical developments from 1836 to today (EPO, Espacenet, 2014).

When a patent corresponds to multiple technological fields, not only the first code of the International Patent Classification (IPC) indicated on the patent is taken into account but all of them. Based on the data on patent applications by IPC subclass, Eurostat calculates data on patent applications in high technology fields. High tech patents are counted following the criteria established by the Trilateral Statistical Report, where the 
subsequent technical fields are defined as high technology: Computer and automated business equipment; micro-organism and genetic engineering; aviation; communications technology; semiconductors; lasers (Eurostat, Patent classifications (...), 2009).

Patentable inventions. European patents shall be granted for any inventions, in all fields of technology, provided that they are new, involve an inventive step and are susceptible of industrial application (EPO, European Patent Convention, article 52, 2013).

Exceptions to patentability. European patents shall not be granted in respect of: (a) inventions the commercial exploitation of which would be contrary to "ordre public" or morality; such exploitation shall not be deemed to be so contrary merely because it is prohibited by law or regulation in some or all of the Contracting States (EPO, European Patent Convention, article 53, 2013).

Novelty. An invention shall be considered to be new if it does not form part of the state of the art. The state of the art shall be held to comprise everything made available to the public by means of a written or oral description, by use, or in any other way, before the date of filing of the European patent application (EPO, European Patent Convention, article 52, 2013). Under the EPC, the novelty of an invention depends upon the "state of the art" as of the filing date (or the priority date, if one is available) of the patent application in question. The general rule is: the first to file, wins. If no one else has made the invention public as of the filing date, or has filed, at an earlier date, a patent application for the same invention, you win. The "state of the art" includes: 1. Everything made available to the public, before the date of filing the European patent application in question, by means of: a. Written description; b. Oral description; c. Use; or d. in any other way. 2. Other European patent applications (EPO, European Patent Convention, 2013).

The search is carried out by highly specialized examiners. The aim is to find the state of the art at the date of filing, in order to determine whether the invention is new and involves an inventive step. Examiners search in databases containing millions of patent documents and non-patent literature. State-of-the-art searches include:

1. World's largest collection of documents (more than 600 million records of patent and non-patent literature documents in over 120 databases, more than 7000 journals, databases updated daily).

2. High-performance EPOQUE search tool (used by examiners, a worldwide benchmark, used by over 40 patent offices, including Australia, Brazil, Canada and China).

3. Machine translation to extend the range of easily accessible information (Goetz, 2014).

4. The combination of science and technology (S\&T) and human resources (HR) is seen as a key ingredient of competitiveness and economic development and also as a means of safeguarding and enhancing our environment over the coming decades. New technologies are being developed and applied, very quickly in many cases. An increasingly skilled and effective workforce will be required if countries are to negotiate the rapid change and new challenges that are emerging in S\&T. Highly skilled human resources are essential for the development and diffusion of knowledge and constitute the crucial link between technological progress and economic growth, social development and environmental well-being. The purpose of this manual is to provide a framework for compiling data on stocks and flows of Human Resources in Science and Technology, for analyzing profiles and trends and for preparing up-to-date series for the users (policymakers and analysts in government, related agencies and the private sector (notably industry), and academics) (Canberra manual, 1995).

5. Within the realm of science and technology indicators, data relating to research and development statistics are undoubtedly of the highest quality since the work has extended over four decades. Nevertheless, changes in the nature of research and development have created new challenges, necessitating a review of how to maintain the relevance of current measurement methods. The sixth revision of the Frascati manual, the most important and standard methodological work for the collection of research and development statistics with worldwide acceptance, first published by OECD in 1963, marks the most recent attempt to improve the statistical methodology for measuring research and development (Frascati manual, 2002; UN Report (...), 2004).

6. A new ad hoc publication on patent statistics was released in September 2003. The aim of this manual is to provide basic information about patent data used in the measurement of science and technology (S\&T), 
the construction of indicators of technological activity, as well as guidelines for the compilation and interpretation of patent indicators. Patent data are complex. It is necessary to have precise knowledge of patenting laws and procedures and the patenting behavior of companies to be able to apply proper controls and filters to the data, obtain meaningful indicators, and interpret them correctly. The complexity of patent data is due to various factors, e.g. the diversity of patent offices and procedures (which can be national or regional in their judicial scope); the variety of ways to file for patent protection (national or international) and the changing behavior of applicants in this regard; and the patent document's differing status and dates in line with the complexity of procedures (applications, grants, international phase, etc.). In addition, experts may still be debating some patent information (value indicators, number of citations / claims, etc.). The Compendium of Patent Statistics presents various patent indicators to reflect the recent trends in innovative activity across a wide range of OECD member and non-member countries. Alongside other science and technology indicators, such as R\&D expenditure and personnel, innovation survey data, etc., patents provide a uniquely detailed source of information on inventive activity. Patent data complement other S\&T data, and it is generally good to use several types of data in conjunction ( $R \& D$, innovation, patents) as a means of cross-validation and to help in interpretation. Patent-based statistics reflect the inventive performance of countries, regions and firms as well as other aspects of the dynamics of the innovation process (cooperation in innovation, technology paths, etc.). Patent indicators, along with other science and technology indicators, thus contribute to our understanding of the innovation system and factors that support economic growth. These indicators have their strengths and weaknesses; they also reflect various stages in the innovation process (OECD Patent Statistics Manual, 2009).

National patenting activity depends on institutional factors, the nature of the legal system and various domestic factors related to the size of the country: the size of the population, of the economy (GDP), and of its R\&D and research community. The statistical properties of patent data are determined by their legal characteristics and by their economic implementation. According to the Patent Statistics Manual a patent document contains a large amount of information, all of which has potential for statistical analysis. For statistical purposes, information contained in a patent document can be grouped into three distinct categories (OECD Patent Statistics Manual, 2009): 1. Technical description of the invention. 2. Development and ownership of the invention. 3. History of the application. Among the few available indicators of technology output, patent indicators are probably the most frequently used. Empirical research has shown that patents are frequently a good predictor of economic and technological performances. Patents statistics are also used to map certain aspects of the dynamics of the innovation process (e.g. co-operation in research, diffusion of technology across industries or countries, etc.), or of the competitive process (the market strategy of businesses); they are also used to monitor the patent system itself. In addition, patents are helpful for tracking globalisation patterns. Patents can also be considered as an intermediate step between R\&D (upstream) and innovation (the invention is used downstream in economic processes). Patent data have advantages and disadvantages for reflecting inventive activities (OECD Patent Statistics Manual, 2009).

Their major advantages are (OECD Patent Statistics Manual, 2009): 1. Patents cover a broad range of technologies. 2. Patents have a close (if imperfect) link to invention. 3. Each patent document contains detailed information on the invention process: a reasonably complete description of the invention, the technology field concerned, the inventors (name, address), the applicant (owner), citations to previous patents and scientific articles to which the invention relates, etc. (WIPO, Standard ST.9, 2013; WIPO, Standard ST.13, 2008; WIPO, Standard ST.16, 2001). 4. The spatial and temporal coverage of patent data is unique. 5. Patent data are quite readily available from national and regional patent offices.

However, as indicators of technological activity, patents have certain drawbacks (OECD Patent Statistics Manual, 2009): 1. Not all inventions are patented. 2. The propensity to file patent applications differs significantly across technical fields. 3 . Several studies have shown that the value distribution of patents is highly skewed. 4. Differences in patent law and practices around the world limit the comparability of patent statistics across countries. 5. Changes in patent laws over the years call for caution when analyzing trends over time. 6. Patent data are complex, as they are generated by complex legal and economic processes. 


\section{Results}

The study was to review the Official bulletins for the years 2005-2014 of State Patent Bureau of the Republic of Lithuania (VPB, Valstybinio patent (...), 2005-2014). The study selected 765 valid patent application published under the Patent Law of the Republic of Lithuania (21 and 26 articles). Aggregated search results are presented in Figure 1.

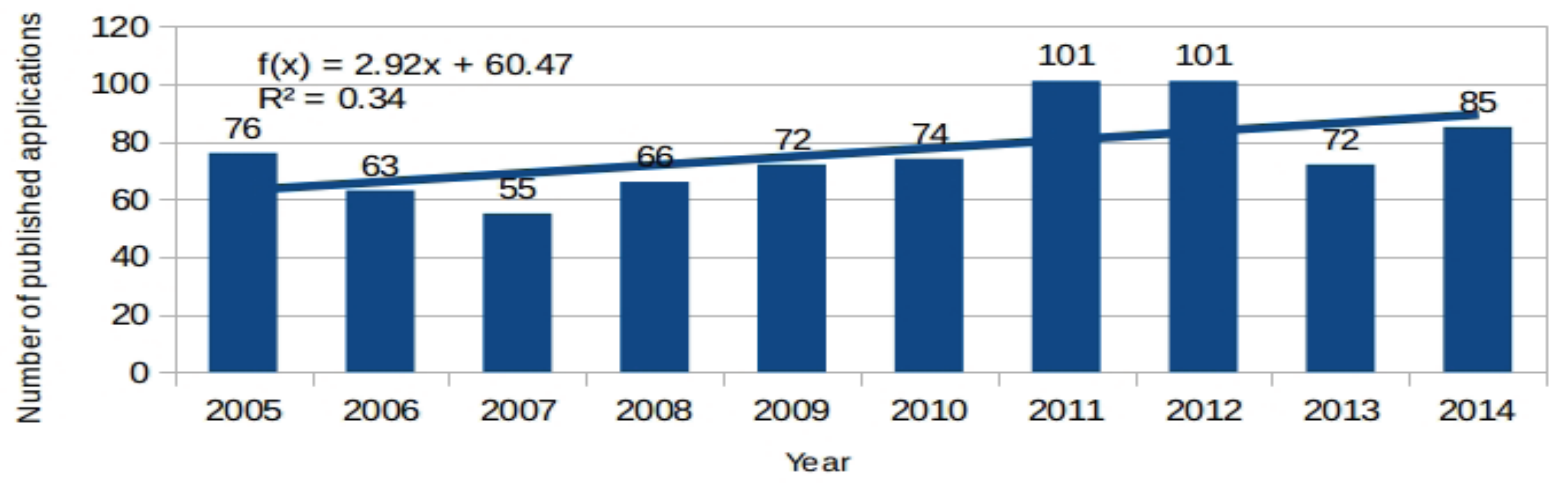

Figure 1. Published applications for inventions made in 2005-2014

Source: developed by the author based on the survey

It was found that the patent for an invention is characterized by the provision in 2005-2014 rising trends (linear regression type, coefficient of determination $R^{2}=0.34$ ).

In Table 1 all published applications for inventions made in 2005-2014 was subdivided into the following groups.

Table 1. Groups of published applications for the 2005-2014 years

\begin{tabular}{|c|c|c|c|}
\hline \multirow{2}{*}{ Groups } & \multicolumn{2}{|c|}{ Applications } & All applications \\
\cline { 2 - 4 } & Lithuania & Foreign countries & \\
\hline Private persons & 300 & 27 & 327 \\
\hline Organizations & 237 & 67 & 304 \\
\hline Universities & 134 & 0 & 134 \\
\hline \multicolumn{2}{|c|}{ Total } & 765 \\
\hline
\end{tabular}

Source: developed by the author based on the survey.

Applicants of private persons and organizations to published applications for the invention exceeds the number of applications submitted by universities.

It was further analyzed the extent to which applicants (inventors) are in a separate published application.

Table 2. The number of applicants in the application in different groups

\begin{tabular}{|c|c|c|c|c|c|c|c|c|c|c|c|}
\hline \multirow[b]{2}{*}{ Groups } & \multicolumn{11}{|c|}{ The number of applicants in the application } \\
\hline & 1 & 2 & 3 & 4 & 5 & 6 & 7 & 8 & 9 & 10 & 12 \\
\hline Private persons & 231 & 122 & 33 & 60 & 20 & 24 & 7 & 0 & 0 & 0 & 0 \\
\hline Organizations & 114 & 122 & 132 & 152 & 130 & 72 & 21 & 24 & 18 & 0 & 12 \\
\hline Universities & 9 & 80 & 99 & 104 & 80 & 48 & 7 & 0 & 0 & 10 & 0 \\
\hline All applicant & 354 & 324 & 264 & 316 & 230 & 144 & 35 & 24 & 18 & 10 & 12 \\
\hline In all applicant & \multicolumn{11}{|c|}{1731} \\
\hline
\end{tabular}

Source: developed by the author based on the survey. 
According to the data in Table 2, it can be said: mostly applicants in private persons groups are mostly 1-2 applicants in every application; mostly applicants in organizations group are mostly 4-3-2-1 applicants in every application; mostly applicants in universities group are mostly 4-3-2-5 applicants in every application. In total published 765 applications are 1731 applicants.

It was found in the 2005-2014 published applications dynamics:

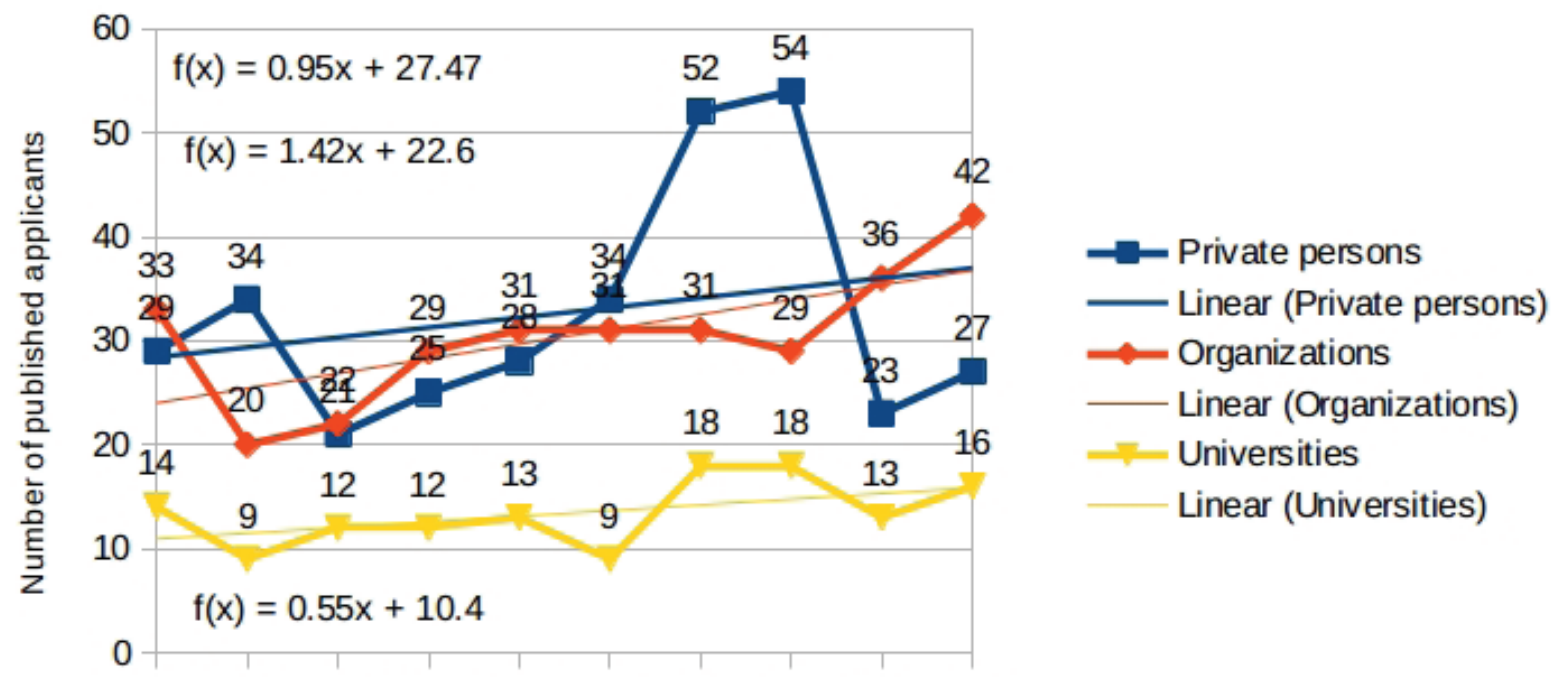

2005200620072008200920102011201220132014

Year

Figure 2. Published applications for inventions of different groups made in 2005-2014 Source: developed by the author based on the survey.

It was found that the applications for an invention is characterized by providing the year 2005-2014 growing linear trend in all groups.

Next set of inventions breakdown of applications by IPC section.

Table 3. The number of published applications in the IPC sections for the 2005-2014 years

\begin{tabular}{|l|c|}
\hline \multicolumn{1}{|c|}{ IPC section } & $\begin{array}{c}\text { Published } \\
\text { applications }\end{array}$ \\
\hline A section. Human necessities & 180 \\
\hline B section. Performing operations; transporting & 120 \\
\hline C section. Chemistry; metallurgy & 97 \\
\hline D section. Textiles; paper & 3 \\
\hline E section. Fixed constructions & 71 \\
\hline F section. Mechanical engineering; lighting; heating; weapons; blasting & 116 \\
\hline G section. Physics & 114 \\
\hline H section. Electricity & 64 \\
\hline & Total \\
\hline
\end{tabular}

Source: developed by the author based on the survey.

According to the data in Table 3, it can be said that the main R \& D specialization in the Republic of Lithuania is: human necessities; performing operations and transporting; mechanical engineering, lighting, heating, weapons, blasting.

It was found that the applications for high technology fields included next IPC subclasses: 
Table 4. The number of published applications for high technology fields in the IPC subclasses for the 2005-2014 years

\begin{tabular}{|l|c|}
\hline \multicolumn{1}{|c|}{ IPC subclasses } & $\begin{array}{c}\text { Number of } \\
\text { applications }\end{array}$ \\
\hline G01H subclass. Measurement of mechanical vibrations or ultrasonic, sonic or infrasonic waves & 14 \\
\hline $\begin{array}{l}\text { GO1B subclass. Measuring length, thickness, or similar linear dimensions; measuring angles; measuring } \\
\text { areas; measuring irregularities of surfaces or contours }\end{array}$ & 14 \\
\hline H01S subclass. Devices using stimulation emission (Lasers) & 13 \\
\hline $\begin{array}{l}\text { H01L subclass. Semiconductor devices; electric solid state devises not otherwise provided for } \\
\text { (Semiconductors) }\end{array}$ & 12 \\
\hline G01F subclass. Measuring volume, volume flow, mass flow, or liquid level; metering by volume & 9 \\
\hline H03K subclass. Tuning resonant circuits; selecting resonant circuits & 7 \\
\hline G01R subclass. Measuring electric variables; measuring magnetic variables & 5 \\
\hline $\begin{array}{l}\text { C12N subclass. Micro-organisms or enzymes; compositions thereof; propagating, preserving, or } \\
\text { maintaining micro-organisms; mutation or genetic engineering; culture media }\end{array}$ & 5 \\
\hline \multicolumn{1}{|c|}{ Total } & 79 \\
\hline
\end{tabular}

Source: developed by the author based on the survey.

According to the data in Table 4, it can be said that the main applications for high technology fields in the Republic of Lithuania included next subclasses: G01H, G01B, H01S, H01L, G01F, H03K, G01R, C12N. It is established that inventors filed 128 applications for high technology fields.

\section{Conclusions}

When analyzing knowledge management it is important to pay attention to various definitions of term knowledge, its classification. A lot of scientific literature concentrates on defining the factors that influence the productivity of knowledge workers and how do they operate in learning organizations. Main models that explain the creation of knowledge within organization are SECI, modified SECI, 7 C, and combined model of knowledge creation. When measuring knowledge the concept of intellectual capital becomes important, as well as patent information, which provides quantifiable indicators for evaluation.

Main tendencies of knowledge creation based on patent information are - among private inventors application for patent usually is submitted by 1-2 inventors, among organizations applications are submitted by $4-3-2-1$ inventors, in universities $4-3-2-5$ inventors.

\section{References}

Bose, R. (2004). Knowledge Management metrics. Industrial Management \& data Systems, Vol. 104, No. 6, p. 457-468. Bose, S., Thomas, K. (2007). Valuation of intellectual capital in knowledge-based firms. Management Decision, Vol. 45, No. 9, p. 1484-1496.

Bratianu, C., Orzea I. (2010). Organizational Knowledge Creation. Management. Marketing Challenges for Knowledge Society, Vol. 5, No. 3, p. 41-62.

Cowan, R., Paal, G. (2000). Innovation Policy in a Knowledge-Based Economy. Available at: http://www.innothessaly. gr/data/Resources/innovation\%20policy\%20in\%20a\%20knowledge\%20based\%20economy.pdf

Daugelienè, R. (2007). The Peculiarities of Knowledge Workers Migration in Europe and the World. Engineering Economics, No. 3 (53), p. 57-64.

Drucker, P. F. (1986). Management. Tasks, Responsibilities, Practices. Truman Talley Books.

Drucker, P. F. (1999). Knowledge-Worker Productivity: The Biggest Challenge. California Management review, Vol. 41, No. 2, p. 79-94. Available at: http://agileconsortium.pbworks.com/w/file/fetch/70970029/knowledge_ workers_the_biggest_challenge.pdf

Drucker, P. F. (2002). The Effective Executive. Available at: ftp://216-80-104-132.mcm-ubr3.chi-mcm.il.static.cable. rcn.com/Books/Business\%20books/Drucker/HBR\%20-\%20The\%20Discipline\%20of\%20Innovation\%20-\%20 Peter\%20Drucker.pdf 
EPO. (2013). European Patent Convention. 15 eponet.nsf/0/00E0CD7FD461C0D5C1257C060050C376/\$File/EPC_15th_edition_2013.pdf

EPO. (2014). Espacenet. Available at: http://www.epo.org/searching/free/espacenet.html

Eurastat. (2009). Patent classifications and technology areas. Available at: http://epp.eurostat.ec.europa.eu/cache/ITY SDDS/Annexes/pat_esms_an4.pdf

Gao, F., Li, M., Nakamori, Y. (2002). Systems thinking and its management: systems methodology for knowledge management. Journal of Knowledge management, Vol. 6, No. 1, p. 7-17.

Goetz, P. A. (2014). An introduction to the EPO and the search activities for The State Patent Bureau of the Republic of Lithuania. Available at: http://www.vpb.gov.lt/docs/20140303_2.pdf

Heinrichs, J. H., Lim, Jen-Su. (2005). Model for Organizational Knowledge Creation and Strategic Use of Information. Journal of the American Society for Information Science and Technology, No. 56 (6), p. 620-629.

Jafari, M., Rezaeenour, J., Akhaven, P. (2009). Identifying Progressive Route of Organizational Knowledge Creation Theory. World Applied Sciences Journal, No. 7 (10), p. 1287-1294.

Mačerinskienė, I., Survilaite, S. (2011). Company’s value added and its intellectual capital coherence. Verslas: teorija ir praktika, Nr. 12 (2), p. 183-192.

Mariam-Webster Dictionary. (2014). Knowledge. Available at: http://www.merriam-webster.com/dictionary/knowledge

Martinez-Fernandez, M. C., Soosay, C. A., Bjorkli, M., Tremayne, K. (2004). Are Knowledge-Intensive Service Activities Enablers of Innovation Processes? A Study of Australian Software Firms. Available at: http://aegis.uws.edu.au/ PDF/CiNet\%20conference\%202004.pdf

Mouritsen, J., Larsen, H. T., Bukh, P. N. (2001). Valuing the future: intellectual capital supplements at Skandia. Accounting, Auditing \& Accountability Journal, Vol. 14, No. 4, p. 399-422.

Nedelea, S., Paun, L. A. (2009). Competitiveness in the Knowledge-Based Economy. Review of International Comparative Management, Vol. 10, Issue 4, p. 745-754.

Nejatian, M., Nejati, M., Zarei, M. H., Soltani, S. (2013). Critical Enablers for Knowledge Creation Process: Synthesizing the Literature. Global Business and Management Research: An International Journal, Vol. 5, No. 2\&3, p. $105-120$.

Nonaka, I. (1991). The Knowledge-Creating Company. Harvard Business Review, July-August 2007, p. $162-171$. Available at: http://midwestkm.com/wp-content/uploads/2013/09/The-Knowledge-Creating-Company-Nonaka.pdf

Nonaka, I., Konno N. (1998). The Concept of "Ba": Building a Foundation for Knowledge Creation. California Management Review, Vol. 40, No. 3, p. 40-54.

Nonaka, I., Toyama, R., Konno, N. (2000). SECI, Ba and Leadership: a Unified Model of Dynamic Knowledge Creation. Long Range Planning, No. 33, p. 5-34.

OECD. (1990). TBP manual. Available at: http://www.oecd.org/science/sci-tech/2347115.pdf

OECD. (1995). Manual on the measurement of human resources devoted to S\&T "Canberra Manual”. Available at: http://www.oecd.org/dataoecd/34/0/2096025.pdf

OECD. (2000). Knowledge Management in the Learning Society. Education and Skills. Available at: http://www.mszs. si/eurydice/pub/oecd/lnowledge.pdf Modified=30ADC05C3D06C50102

OECD. (2002). Frascati Manual. Available at: http://europa.eu.int/estatref/info/sdds/en/rd/rd_frascati_manual_2002. pdf

OECD. (2005). Oslo Manual. Guidelines for Collecting and Interpreting Innovation Data. $3^{\text {Rd }}$ edition. Available at: http://ulutek.uludag.edu.tr/downloads/Oslo_Manual_Third_Edition.pdf

OECD. (2009). OECD Patent Statistics Manual. Available at: http://www.oecdbookshop.org/oecd/get-it. asp?REF=9209021E.PDF\&TYPE=browse

Oinas-Kukkonen, H. (2004). The 7C Model for Organizational Knowledge Creation and Management. Available at: http://www.cream.oulu.fi/english/documents/Harri_Oinas-Kukkonen_artikkeli.pdf

Oinas-Kukkonen, H. (2005). Towards evaluating knowledge management through the 7C Model. Available at: http:// www.researchgate.net/publication/228951586_Towards_evaluating_knowledge_management_through_the_7C_ model/links/02e7e52838f73c24d8000000

Oxford Dictionaries. (2014). Definition of knowledge. Available at: http://www.oxforddictionaries.com/definition/english/knowledge

Pollock, N. (2002). Knowledge Management and Information Technology (Know-IT Encyclopedia). Available at: http:// www.au.af.mil/au/awc/awcgate/dau/know-it.pdf

Prasad, B. (1998). Decentralized cooperation: a distributed approach to team design in a concurrent engineering organization. Team Performance Management, Vol. 4, No. 4, p. 138-165.

Quereshi, S., Briggs, R. O. (2006). Value Creation from Intellectual Capital: Convergence of Knowledge Management and Collaboration in the Intellectual Bandwidth Model. Group Decision and Negotiations, No. 15, p. 197-220. 
Raisanen, T., Oinas-Kukkonen, H. (2008). A system Architecture for the 7C Knowledge Environment. Available at: http://www.epd.aau.dk/uploads/media/ejc_7c_information_system_architecture_final.pdf

Ramanauskaitè, A., Rudžionienè, K. (2013). Intellectual capital valuation: methods and their classification. Ekonomika, Nr. 92 (2), p. 79-92.

Senge, P. M. (1990, 2004). The Fifth Discipline. Available at: https://duckduckgo.com/l/?kh=-1\&uddg=http $\% 3 \mathrm{~A} \% 2 \mathrm{~F}$ \%2F4grantwriters.com\%2FPeter_Senge_The_Fifth_Discipline_1_1_.pdf

Smith, M. K. (2003). Michael Polanyi and tacit knowle $\overline{d g}$ e, the encyclopedia of informal education. Available at: http:// www.infed.org/thinkers/polanyi.htm

Soviar, J., Zavodska, A. (2011). Knowledge and its creation-the case of introducing product to the market. Verslas: teorija ir praktika, Nr. 12 (4), p. 362-368.

Sulaiman, R. V., Thummuru, L., Hall, A., Dijkman, J. (2009). Tacit Knowledge and Innovation Capacity: Evidence from Indian Livestock Sector. Available at: http://www.merit.unu.edu/publications/wppdf/2009/wp2009-058.pdf

Sveiby, K. E. (2001). Towards a Knowledge-based Theory of the Firm. Article for Journal of Intellectuall Capital, Vol. 2, No. 4, p. 1-15. Available at: http:/www.sveiby.com/articles/knowledgetheoryoffirm.htm

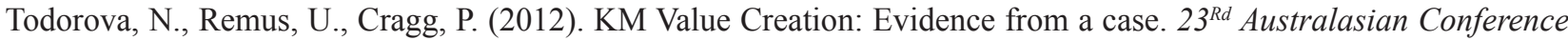
on Informations Systems, p. 1-9.

UN. (2004). Report of the United Nations Educational, Scientific and Cultural Organization and the Organization for Economic Cooperation and Development on statistics of science and technology. Available at: http://www.uis.unesco.org/Library/Documents/st03_en.pdf

Vaškelienè, L. (2007). Development of Organizational Intellectual Capital Measurement Methodology: problems and solutions. Economics and management, No. 12, p. 167-174.

Vorakulpipat, C., Rezgui, Y. (2006). From Knowledge Sharing to Value Creation: Three generations of Knowledge Management, IEEE, Vol. 7, No. 6, p. 215-220.

Vorakulpipat, C., Rezgui, Y. (2007). Value Creation: The Next Generation of Knowledge Management. IRMA International Conference, p. 1-5.

Vorakulpipat, Ch., Rezgui Y. (2008). An evolutionary and interpretive perspective to knowledge management. Journal of knowledge management, Vol. 12, No. 2008, p. 17-34.

VPB. (2014). Valstybinio patentu biuro biuletenis. (2005-2013). Available at: http://www.vpb.lt/index.php?n=139\&1=lt WIPO. (2001). Standard ST.16. Available at: http://www.wipo.int/export/sites/www/standards/en/pdf/03-16-01.pdf WIPO. (2008). Standard ST.13. Available at: http://www.wipo.int/export/sites/www/standards/en/pdf/03-13-01.pdf WIPO. (2013). Standard ST.9. Available at: http://www.wipo.int/export/sites/www/standards/en/pdf/03-09-01.pdf WIPO. (2014). IPC full edition. Available at: http://www.wipo.int/ipc/itos4ipc/ITSupport_and_download_ area/20120101/pdf/scheme/full_ipc/en/ipc_en_full_ipc_20120101.zip

WIPO. (2014). Paris Convention for the Protection of Industrial Property. Available at: http://www.wipo.org/clea/docs/ en/wo/wo020en.htm

\section{ŽINIŲ PLITIMAS LIETUVOJE PASKELBTŲ PATENTINIU PARAIŠKŲ POŽI ŪRIU}

Arimantas BronisLovas KNAŠAS

Klaipèdos universitetas (Lietuva)

\section{Santrauka}

Šiame straipsnyje nagrinėjami pagrindiniai žiniu termino apibrèžimai ir žinių klasifikavimo klausimai. Aprašomi pagrindiniai „žinių darbininkų“ produktyvumą lemiantys veiksniai, 5 besimokančios organizacijos dalykai. Aprašomi ir lyginami pagrindiniai žinių kūrimo modeliai SECI, išplèstas SECI modelis, 7C elementų modelis, mišrus žinių tyrimo modelis. Analizuojami mokslininkų žinių vertès kūrimo darbai, pabrèžiama intelektinio kapitalo reikšmè organizacijos veikloje ir ịvairūs intelektinio kapitalo matavimo rodikliai. Išanalizavus mokslo ir technologijų rodiklių aprašymą tarptautiniuose oficialiuose dokumentuose pabrěžiama patentinès informacijos ir patentinès dokumentacijos reikšmè. Atliekant tyrimą iš 2005-2014 
metų valstybinių patentų biuletenių išrinktos paskelbtos išradimų paraiškos. Nustatytos išradimų paraiškų vystymosi tendencijos, privačių asmenų, organizacijų ir universitetų paraiškų pateikimas, pagrindinès MTEP vystymo tendencijos Lietuvoje. Nustatyta: privačių asmenų grupëje paraiškas teikia 1-2 išradèjai, organizacijų grupejje $-4-3-2-1$ išradejjai, universitetų grupẻje $-4-3-2-5$ išradẻjai. Tyrimu nustatyta, kad paraiškos pagal Tarptautinę patentų klasifikaciją priskirtinos aukštosioms technologijoms.

PAGRINDINIAI ŽODŽIAI: žinių kūrimas, žiniu vertè, intelektinis kapitalas, patentinè paraiška.

JEL KLASIFIKACIJA: D80, O31, O34. 